\title{
Fertility in cows after treatment with a prostaglandin analogue with or without progesterone
}

\author{
J. F. Roche \\ The Agricultural Institute, Grange, Co. Meath, Ireland
}

\begin{abstract}
Summary. Two injections each of $500 \mu \mathrm{g}$ Cloprostenol (ICI-80,996), a synthetic analogue of PGF-2 $\alpha, 11$ or 12 days apart or pretreatment for 7 days with progesterone from an intravaginal silastic coil and one injection of $500 \mu \mathrm{g}$ Cloprostenol were both effective in synchronizing oestrus in heifers or nursing beef cows. After two inseminations at 72 and $96 \mathrm{hr}$ after the end of treatment, the calving rate for cows observed in oestrus after both treatments or for cows that had oestrous-like mucus after the progesterone+Cloprostenol treatment did not differ from that of control cows, but was significantly $(P<0.025)$ lower for cows diagnosed as ready for insemination by the characteristics of mucus after the two injections of Cloprostenol. Treated cows diagnosed per rectum as having inactive ovaries had a significantly $(P<0 \cdot 005)$ lower calving rate than those diagnosed as having active ovaries at the start of treatment. Significantly $(P<0.005)$ more treated than control cows were inseminated and became pregnant in the first 15 days of the treatment period, but the overall level of reproductive efficiency was low.
\end{abstract}

\section{Introduction}

Treatment with prostaglandin (PG) F-2 $\alpha$ (Rowson, Tervit \& Brand, 1972; Lauderdale, 1972; Inskeep, 1973; Roche, 1974) or synthetic analogues of PGF-2 $\alpha$ (Tervit, Rowson \& Brand, 1973; Cooper, 1974) is effective in causing luteolysis in heifers or cows except for 4 or 5 days after oestrus (Rowson et al., 1972; Louis, Hafs \& Seguin, 1973). A regimen consisting of two injections of PG 10-12 days apart has been shown to synchronize oestrus in randomly cycling animals (Cooper, 1974; Hafs, Manns \& Drew, 1975) and pretreatment of heifers for 5 days with a synthetic progestagen followed by a single injection of PGF-2 $\alpha$ is also effective (Wishart, 1974). Fertility following insemination at the synchronized oestrus induced by PG treatment has been reported to be normal (Inskeep, 1973; Lauderdale et al., 1974; Roche, 1974; Cooper \& Jackson, 1975; Hafs et al., 1975).

The normal calving rate of lactating cows is about $50 \%$ after a single insemination (Esselmont, 1974; Spalding, Everett \& Foote, 1975). To improve reproductive efficiency, it is necessary to inseminate cows early in the breeding season so that repeat inseminations can be performed early, thereby achieving a more compact calving season (Wiltbank, 1970; Macmillan, 1974). The aim of the present work was to determine the efficacy of the double injection regimen of a synthetic analogue of PGF-2 $\alpha$, ICI-80,996 (Cloprostenol: ICI Ltd, U.K.) to synchronize breeding in nursing beef cows under commercial management, and to determine whether or not pretreatment with progesterone for 7 days followed by a single injection of Cloprostenol would synchronize breeding and result in normal fertility to inseminations given on a fixed-time basis.

\section{Materials and Methods}

\section{Preliminary experiment}

Seventy-two normal Hereford-cross heifers received 2 i.m. injections each of $500 \mu \mathrm{g}$ Cloprostenol 11 days apart. KaMaR heatmount detectors (Kamar Inc, Steamboat Springs, Colorado 80477, 
U.S.A.) were placed on the back of each animal $48 \mathrm{hr}$ after the second injection and the animals were observed at 48, 72 and $96 \mathrm{hr}$ for oestrus. Standing to be mounted, or the presence of an exposed KaMaR and physical evidence of animals having been mounted, were taken as indicators of oestrus. Cervical mucus was obtained and examined from animals not in oestrus at $48 \mathrm{hr}$. Clear mucus of low viscosity, characteristic of animals in oestrus, was taken to indicate that the animals had responded to treatment.

\section{Experiment 1}

On a dairy farm, 42 Friesian dairy cows $>40$ days post partum were allocated randomly to two groups. Group A cows received intravaginal silastic coils impregnated with progesterone (Roche, 1976). After 7 days, the coils were removed and an i.m. injection of $500 \mu \mathrm{g}$ Cloprostenol was given. Animals in Group B were untreated controls. The animals were checked morning and evening for oestrus and those in oestrus were artificially inseminated with frozen semen towards the end of, or shortly after, oestrus. Cows that did not return to oestrus were allowed to calve. On the same farm, 16 heifers were given the same treatment as Group A cows and 16 similar heifers were mated to a bull and served as controls. Pregnancy was determined by rectal examination 3 months after insemination of all heifers not returning to oestrus.

\section{Experiment 2}

On 6 farms, autumn-calving nursing beef cows (mainly Hereford cross) were used. Rectal examination was carried out on 143 cows and ovarian activity was classified as (i) active, when a palpable CL or a large follicle was found, or the ovary was of normal size and consistency although no distinguishable structure was detected, or (ii) inactive, when two small hard ovaries with no palpable structures were found. On Farm 1, cows were 51-160 days post partum and they received 2 i.m. injections of Cloprostenol 12 days apart. On Farms 2, 3, 5 and 6, the animals ( $>46$ days post partum) were allocated to groups according to the post-partum interval and on Farm 4 ( $>100$ days post partum) completely at random. The three treatment groups were (a) control, (b) two i.m. injections of Cloprostenol 11 or 12 days apart, and (c) progesterone coils for 7 days+Cloprostenol at removal of coils. Vasectomized bulls with chin-ball mating devices were run with the cows on all farms except Farm 4. Observations for oestrus were carried out three times daily on this farm. The control cows were artificially inseminated as they showed oestrus beginning on the 1st day of treatment, and detection of oestrus continued for 60 days. Treated cows without characteristic paint marks had a sample of mucus taken 48 or $72 \mathrm{hr}$ after the end of treatment. Cows in oestrus or those secreting mucus indicative of oestrus were artificially inseminated at 72 and $96 \mathrm{hr}$ after the end of treatment; animals not returning to oestrus were allowed to calve.

\section{Experiment 3}

On 5 farms, spring-calving nursing beef cows (mainly Hereford cross) at pasture were used. Control cows were available on two farms. Animals were allocated to the three treatment groups described for Exp. 2 according to the post-partum interval on these 2 farms, and completely at random on the remainder. The treatments used and times of artificial insemination were the same as in Exp. 2 except that cervical mucus samples were not taken. A rectal examination for pregnancy was carried out $65-86$ days after insemination.

\section{Results}

\section{Preliminary experiment}

Of the 72 heifers treated, 30 were observed in oestrus at $48 \mathrm{hr}, 21$ at $72 \mathrm{hr}$ and 8 at $96 \mathrm{hr}$ after the second injection of Cloprostenol. Of the 13 animals that were not seen in oestrus, 8 had mucus that was characteristic of oestrus $48 \mathrm{hr}$ after the second injection of Cloprostenol. 


\section{Experiment 1}

Of the 21 cows that were treated, 18 were observed in oestrus 2-5 days after removal of the coils; 2 on Day 2, 7 on Day 3, 6 on Day 4 and 3 on Day 5. Two of the remaining 3 cows were observed in oestrus 26 and 28 days after removal of the coils while the last cow was in oestrus 58 days after removal of the coil. Fourteen of the 21 treated cows calved and 12/21 control cows calved to first insemination. Fifteen of 16 treated heifers were observed in oestrus following removal of the coils; 9 on Day 2, 5 on Day 3 and 1 on Day 4. Eight treated and 10 control heifers that did not return to oestrus were diagnosed pregnant.

Table 1. The results of synchronization treatments on nursing beef cows in the autumn on Farms 2, 3, 4, 5 and 6

\begin{tabular}{|c|c|c|c|c|c|}
\hline $\begin{array}{l}\text { Days after } \\
\text { start of } \\
\text { treatment }\end{array}$ & $\begin{array}{l}\text { No. assigned } \\
\text { to treatment }\end{array}$ & $\begin{array}{l}\text { No. } \\
\text { inseminated }\end{array}$ & $\begin{array}{l}\text { No. } \\
\text { calved }\end{array}$ & $\frac{\text { No. calved }}{\text { No. inseminated }} \times 100$ & $\frac{\text { No. calved }}{\text { No. treated }} \times 100$ \\
\hline \multicolumn{6}{|l|}{ Control } \\
\hline Days $0-15$ & & 21 & 9 & 43 & 13 \\
\hline Days $16-30$ & & 17 & 8 & 47 & 12 \\
\hline Days 31-60 & & 16 & 6 & 38 & 9 \\
\hline Total & 68 & 54 & 23 & 43 & 34 \\
\hline $\begin{array}{l}\text { Cloprostenol }+ \\
\text { Cloprostenol }\end{array}$ & & & & & \\
\hline $\begin{array}{l}\text { Days 0-15 } \\
\text { Progesterone }+ \\
\text { Cloprostenol }\end{array}$ & 65 & 46 & $19^{*}$ & 41 & 29 \\
\hline Days 0-15 & 63 & 55 & $27^{*}$ & 49 & 43 \\
\hline
\end{tabular}

* Significantly different $(P<0 \cdot 005)$ from controls.

\section{Experiment 2}

On Farm 1, of 25 cows diagnosed with active ovaries, 16 were inseminated and 7 subsequently calved; of 20 cows with inactive ovaries, 7 were inseminated and 1 subsequently calved. The results from the remaining farms are shown in Table 1. Significantly $(P<0.005)$ more treated cows became pregnant during the first 15 days after the start of treatment compared to the number of control cows which became pregnant during this time. The calving rate of cows observed in oestrus after both treatments $(34 / 65,52 \%)$ was not different from that of controls $(23 / 54,43 \%)$; but the calving rate for cows inseminated on the basis of oestrous-like mucus after the Cloprostenol+Cloprostenol treatment $(10 / 28,26 \%)$ was significantly $(P<0.025)$ lower than the calving rate in treated cows which were observed in oestrus $(19 / 35,54 \%)$. The calving rates after the progesterone+Cloprostenol treatment were similar (12/25 calving from insemination on the basis of oestrous-like mucus and 15/30 from insemination at oestrus). There was a significant $(P<0.005)$ reduction in calving rate after insemination of cows with inactive ovaries compared to that for cows with active ovaries at the start of treatment (Table 2).

Table 2. Effect of ovarian condition, determined at start of treatment by rectal examination, on calving rate in synchronized cows

\begin{tabular}{|c|c|c|c|c|}
\hline & \multicolumn{2}{|c|}{ Cloprostenol + Cloprostenol } & \multicolumn{2}{|c|}{ Progesterone + Cloprosteno } \\
\hline & Active & Inactive & Active & Inactive \\
\hline Total no. of cows & 73 & 30 & 28 & 12 \\
\hline Cows observed in oestrus & 31 & 4 & 11 & 4 \\
\hline No. of cows calving & 19 & 0 & 7 & $\mathbf{0}$ \\
\hline Cows with oestrous-like mucus & 22 & 8 & 12 & 5 \\
\hline No. of cows calving & 7 & 2 & 6 & 0 \\
\hline Cows calving/cows inseminated $(\%)$ & 49 & 17 & 57 & $\mathbf{0}$ \\
\hline Cows calving/cows treated $(\%)$ & 36 & 7 & 46 & $\mathbf{0}$ \\
\hline
\end{tabular}


Table 3. Fertility after synchronization of oestrus in nursing cows at pasture from March to September 1974

\begin{tabular}{lccc}
\hline & Controls & $\begin{array}{c}\text { Cloprostenol + } \\
\text { Cloprostenol }\end{array}$ & $\begin{array}{c}\text { Progesterone + } \\
\text { Cloprostenol }\end{array}$ \\
\hline No. treated & 39 & 89 & 61 \\
No. inseminated & 36 & 87 & 61 \\
No. returning to oestrus & 13 & 37 & 16 \\
No. pregnant & 19 & 39 & 37 \\
Cows pregnant/cows inseminated $(\%)$ & 50 & 45 & 60 \\
Cows pregnant/cows treated $(\%)$ & 49 & 44 & 60 \\
\hline
\end{tabular}

\section{Experiment 3}

The results of the treatments to spring-calving cows are shown in Table 3 . A higher proportion $(P<0 \cdot 05)$ of cows became pregnant after the progesterone+Cloprostenol regimen than in the control or other treatment group.

\section{Discussion}

The double-injection regimen of Cloprostenol was highly effective in synchronizing oestrus in heifers and the time of onset of oestrus was similar to that reported by Cooper (1974). Treatment with progesterone for 7 days before giving a single injection of Cloprostenol was also effective. The fixedtime inseminations used in these experiments also appeared to be satisfactory to achieve normal fertility in cows that responded to either treatment. Cows with inactive ovaries at the start of treatment responded to neither treatment. The number of nursing beef cows with inactive ovaries in autumncalving herds in the present study was high even in cows up to 60 days post partum, possibly because of a low plane of nutrition, since level of nutrition is a major factor affecting resumption of normal reproductive activity in beef cows (Wiltbank, 1970). Although rectal examination is a crude method of determining the functional state of the ovaries, it may be valuable, as in the present experiments, to identify animals which are unlikely to respond to the treatments described here. What effect, if any, palpation of the ovaries has on stimulating ovarian activity is not known.

Behavioural symptoms of oestrus in the control and treated cows were difficult to detect. Few cows were observed in standing oestrus and, in the absence of vaspctomized marker bulls, many would have been missed. Of those not marked, examination of cervical mucus was a valuable method of identifying cows which had responded to treatment sufficiently to be suitable for insemination, especially after treatment with progesterone + Cloprostenol (Exp. 2).

The overall level of reproductive efficiency was low in the control and treated animals in these experiments, high-lighting the need for further research in this area. The results of Exps 2 and 3 , however, indicated the value of pretreatment with progesterone on fertility but the mechanism of action is not clear. Corah, Quealy, Dunn \& Kaltenbach (1974) and Folman, Rosenberg, Herz \& Davidson (1973) observed that fertility was better in cows with high circulating progesterone levels during the cycle before conception and the effect may be similar to that of a silent ovulation at the start of the breeding season. Further experiments are required to see if this effect is repeatable.

I thank Dr M. J. Cooper of I.C.I. Ltd, U.K., for supplying Cloprostenol and for valuable comments during the work and criticisms on the manuscript; Mr D. Prendiville and $\mathrm{Mr} W$. Davis for excellent technical help; and the farmers involved for their co-operation at all times.

\section{References}

COOPER, M.J. (1974) Control of oestrous cycles of heifers with a synthetic prostaglandin analogue. Vet. Rec. 95, 200-203.

COOPER, M.J. \& JACKSON, P. (1975) Control of the bovine oestrous cycle with a synthetic prostaglandin analogue ICI-80996-preliminary field experiences in lactating beef cattle. Proc. Br. Soc. Anim. Prod. 4 115-116. 
Corah, L.R., Quealy, A.P., Dunn, T.G. \& KaltenBACH, C.C. (1974) Prepartum and postpartum levels of progesterone and estradiol in beef heifers fed two levels of energy. J. Anim. Sci. 39, 380-385.

ESSELMONT, R.J. (1974) Economic and husbandry aspects of the manifestation and detection of oestrus in cows. Part 1 . Economic aspects. $A D A S Q$. Rev. 12, 175-184.

Folman, Y., Rosenberg, M., Herz, Z. \& Davidson, M. (1973) The relationship between plasma progesterone concentrations and conception in post-partum dairy cows maintained on two levels of nutrition.J. Reprod. Fert. 34, 267-278.

Hafs, H.D., Manns, J.G. \& Drew, B. (1975) Onset of oestrus after prostaglandin $\mathrm{F}_{2 \alpha}$ in cattle. Vet. Rec. 96, 134-135.

INSKeEP, E.K. (1973) Potential uses of prostaglandins in control of reproductive cycles in domestic animals. J. Anim. Sci. 36, 1149-1157.

LAUdERDALE, J.W. (1972) Effects of PGF P $_{2 \alpha}$ on pregnancy and estrous cycle of cattle. J. Anim. Sci. 35, 246.

Lauderdale, J.W., Seguin, B.E., Stellflug, J.N., Chenault, J.R., Thatcher, W.W., Vincent, C.K. \& Loyancano, A.F. (1974) Fertility of cattle following PGF $_{2 \alpha}$ injection. J. Anim. Sci. 38, 964-967.

Louis, T.M., HaFs, H.D. \& Seguin, B.E. (1973) Progesterone, $\mathbf{L H}$, estrus and ovulation after pros- taglandin $\mathrm{F}_{2 \alpha}$ in heifers. Proc. Soc. exp. Biol. Med. 143, 152-155.

Macmillan, K.L. (1974) The application of artificial breeding as a reproductive technique in cattle. Proc. N.Z. Soc. Anim. Prod. 34, 158-166.

Roche, J.F. (1974) Synchronization of oestrus and fertility following artificial insemination in heifers given prostaglandin $\mathrm{F}_{2 \alpha} . J$. Reprod. Fert. 37, 135-1 38.

RoCHE, J.F. (1976) Retention rate in cows and heifers of intravaginal silastic coils impregnated with progesterone. J. Reprod. Fert. 46, 253-255.

Rowson, L.E.A., Tervit, H.R. \& Brand, A. (1972) The use of prostaglandins for synchronization of oestrus in cattle. J. Reprod. Fert. 29, 145-148.

Spalding, R.W., EveretT, R.W. \& Foote, R.H. (1975) Fertility in New York artificially inseminated Holstein herds in dairy herd improvement. $J$. Dairy Sci. 58, 718-723.

Tervit, H.R., Rowson, L.E.A. \& Brand, A. (1973) Synchronization of oestrus in cattle using a prostaglandin $\mathrm{F}_{2 \alpha}$ analogue (ICI-80996). J. Reprod. Fert. 34, 179-181.

Wiltbank, J.N. (1970) Research needs in beef cattle reproduction. J. Anim. Sci. 31, 755-762.

WishaRT, D.F. (1974) Synchronization of oestrus in cattle using a potent progestin (SC-21009) and $\mathrm{PGF}_{2 a}$. Theriogenology 1, 87-90.

Received 23 June 1975 